\title{
Understanding platform business models: A mixed methods study of marketplaces
}

DOI:

10.1016/j.emj.2017.06.005

\section{Document Version}

Accepted author manuscript

Link to publication record in Manchester Research Explorer

\section{Citation for published version (APA):}

Taeuscher, K., \& Laudien, S. M. (2018). Understanding platform business models: A mixed methods study of marketplaces. European Management Journal, 36(3), 319-329. https://doi.org/10.1016/j.emj.2017.06.005

\section{Published in:}

European Management Journal

\section{Citing this paper}

Please note that where the full-text provided on Manchester Research Explorer is the Author Accepted Manuscript or Proof version this may differ from the final Published version. If citing, it is advised that you check and use the publisher's definitive version.

\section{General rights}

Copyright and moral rights for the publications made accessible in the Research Explorer are retained by the authors and/or other copyright owners and it is a condition of accessing publications that users recognise and abide by the legal requirements associated with these rights.

\section{Takedown policy}

If you believe that this document breaches copyright please refer to the University of Manchester's Takedown Procedures [http://man.ac.uk/04Y6Bo] or contact uml.scholarlycommunications@manchester.ac.uk providing relevant details, so we can investigate your claim.

\section{OPEN ACCESS}




\section{Understanding Platform Business Models: A Mixed Methods Study of Marketplaces}

Citation: Täuscher, Karl \& Laudien, Sven (2018): Understanding platform business models: A mixed methods study of marketplaces, European Management Journal, 36(3), 319-329.

DOI: https://doi.org/10.1016/j.emj.2017.06.005

Available online at:

https://www.sciencedirect.com/science/article/pii/S0263237317300853 


\begin{abstract}
Recent technological advances have enabled the emergence of novel business models based on digital platforms. Marketplace like Airbnb or Uber offer such digital platforms to connect previously unmatched demand-side and supply-side participants through innovative forms of value creation, delivery and capture. While countless firms claim to offer the next 'Airbnb for X' or 'Uber for Y', we lack knowledge about the defining business model characteristics of these marketplaces. To close the gap, this paper provides a conceptually and empirically grounded taxonomy of their business models. Applying a mixed methods approach, it first develops an integrative framework of marketplace business models. Guided by the framework, the research systematically analyzes 100 randomly selected marketplaces with content analysis and binary coding. The gathered data is analyzed with cluster analysis techniques to develop a taxonomy for marketplace business models. The clustering process reveals six clearly distinguishable types of marketplace business models and thus shows that there is no one-size-fits-all approach to creating, delivering, and capturing value with marketplaces and platforms in general. We characterize these distinctive types on basis of the qualitative and quantitative findings. Among others, we find that two of these types are highly aligned with business model characteristics associated with the so-called sharing economy. The findings are discussed against platform, marketplace, and sharing economy literature to contribute to a higher integration of different literature streams that are concerned with similar organizational types and phenomena.
\end{abstract}

Key words: Business Models, Marketplaces, Platforms, Mixed Methods Approach, Digital Economy

\title{
1 Introduction
}

Marketplaces - such as Airbnb or Uber - open new ways for radical changes in the organization of economic activities (Parker et al., 2016). Marketplaces, a rapidly emerging category of platforms (Gawer, 2014; McIntyre \& Srinivasan, 2016), enable and support transactions between independent supply- and demand-side participants. Also discussed as transaction platforms (Evans \& Gawer, 2016), they are characterized by their open business models that inherently rely on independent participants to co-create value. As they trigger network effects between the demand and supply side, they are particularly associated with rapid growth and the potential to dominate a market due to winner-take-all dynamics (Hagiu \& Wright, 2015). As such, scholars from diverse fields have become interested in these organization types (McIntyre \& Srinivasan, 2016; Gawer, 2014) and even suggest that they can become a core organizing principle for a new economy (Kenney \& Zysman, 2016; Parker et al., 2016).

To date, however, there is a lack of understanding about the distinctive business model configurations of marketplaces. While scholars have been interested in internet-enabled marketplaces since the late 1990s (Bakos, 1998; Brunn et al., 2002; Ordanini \& Pol, 2001; Vesa \& van Heck, 2005), existing literature focuses primarily on business-to-business marketplaces as institutions for efficient procurement and sourcing within established industry 
settings (Choudhury et al., 1998; Dai \& Kauffman, 2001; Giaglis et al., 2002). Yet, recent technological advances, such as novel search and matching algorithms or the broad diffusion of mobile devices, enabled the development of innovative marketplace business models that address diverse consumer markets, including transportation (Uber), accommodation (Airbnnb), or finance (Lending Club). Such marketplaces often provide entirely new value propositions, apply novel revenue models, or build on the assets of private individuals to create value (Parker et al., 2016). Their attractiveness is, among others, evidenced by more than 30 private marketplace firms that are currently valued at more than a billion dollars (CB Insights, 2017). Given these high valuations, it is not surprising that several hundred firms have launched new marketplaces over the last years, including an increasing number of new ventures that claim to provide an "Airbnb for X" or "Uber for Y". Examples range from 'Airbnb for food with strangers' (BonAppetour), 'Airbnb for 3D printing' (3D Hubs) to 'Airbnb for toilets' (Airpnp). In many cases, however, the meaning of these analogies remains ambiguous. As we lack a clear understanding about different types of marketplace business models, findings in related research streams - including research on the 'sharing economy' (Möhlmann, 2015; Sundararajan, 2016; Zervas et al., 2013) or 'gig economy' (Friedman, 2014) - remains largely unconnected and isolated. As such, we observe a great need for a more holistic perspective on how marketplaces create, deliver, and capture value through their business model configurations. To address this need, we aim at exploring the distinctive types of marketplace business models through a systematic study of their elements. The paper thus aims at answering two questions: (1) What are the business model types for marketplaces? (2) What value creation, delivery, and capture mechanisms characterize these types?

To answer these questions, we apply a mixed methods approach. Against the background of business model, marketplace, and platform literature, we develop an integrative framework that helps us identify the elements and competing options in marketplace business models. We subsequently use the developed framework to classify the business models of 100 randomly identified marketplaces along 24 elements, employing a qualitative content analysis. In a second step, we explore the relatedness of the business models along multiple dimensions using cluster analysis techniques. The identified clusters and an in-depth analysis of representative cluster firms allow for the development of a novel taxonomy and a systematic conceptualization of marketplace business models. The study demonstrates the value of the business model concept as a unit of analysis for classifying and exploring platforms. The empirical taxonomy further contributes to the marketplace literature by shedding light on how new digital technologies broaden the options for creating, delivering, and capturing value with platforms. The article discusses how our findings relate to previous marketplace and platform literature and how they can contribute to a more integrative and holistic approach to the exploration of such novel organizational types.

\section{Theory}

This research focuses on marketplaces that are enabled by digital technologies. Since previous definitions often relate to marketplaces as institutions rather than businesses, we propose four conditions for classifying a firm as a marketplace. First, digital marketplaces connect independent actors from a demand and supply side (individuals or organizations) via a digital platform (Bakos, 1998). Individual actors can, however, participate in the market on 
both, the supply side and the demand side, and therefore do not necessarily represent different groups of participants. Second, these actors enter direct interactions with each other to initiate and realize commercial transactions. These interactions go beyond the highly automated processes in electronic commodity trading or stock markets. Third, the marketplace platform provides an institutional and regulatory frame for transactions. This criterion excludes internet portals that offer algorithmic aggregation of different marketplaces (Parker \& van Alstyne, 2015). Fourth, the platform does not substantially produce or trade goods or services itself. This condition excludes business models of producers or retailers that additionally allow other parties to offer goods via their digital platform (Hagiu \& Wright, 2015). Digital marketplaces in the sense of this study differ from the conceptualizations of electronic markets or marketplaces (e.g. Wang et al., 2008) through the focus on the marketplace as a business rather than an institutional or technological phenomenon. In fact, first empirical insights suggest that these new types of digital marketplaces are far more disruptive on their industries than the first wave of internet-enabled marketplaces that primarily focused on providing more efficient B2B transactions (Parker et al., 2016).

Analyzing the business models of digital marketplaces further requires an understanding of the business model (BM) as unit of analysis. The BM concept can be distinguished from other units of analysis - such as strategy - by a holistic, boundary spanning perspective that includes firm internal as well as firm external elements (Zott et al., 2011). Yet, business model research has operationalized the concept in a variety of forms, ranging from a description of elements (Osterwalder, 2004; Johnson, 2010; Abdelkafi et al., 2013) to identifying underlying design themes (Amit \& Zott, 2001; Zott \& Amit, 2007; Brettel et al., 2012). Saebi and Foss (2015) provide a good overview of the variety of business model definitions. A recent review by Täuscher and Abdelkafi (2017) reveals that the variety of competing understandings can be classified into three business model views, but that literature is far from converging towards a common understanding of the business model concept. The same holds true for business model innovation - a concept that also recently gained high interest in business administration research, but lacks a clear and widely accepted definition (Spieth et al., 2014).

Aiming at providing a traceable understanding of the employed business model concept, this research follows the definition by Teece (2010) who describes a business model as "the design or architecture of the value creation, delivery and capture mechanisms employed. The essence of a business model is that it crystallizes customer needs and their ability to pay, defines the manner by which the business enterprise responds to and delivers value to customers, entices customers to pay for value, and converts those payments to profit through the proper design and operation of the various elements of the value chain". In line with this description, researchers often refer to the distinctive business model dimensions of (1) value creation (2) value delivery, and (3) value capture (Teece, 2010).

To develop a framework for our analysis, we focus on the business model elements and their potential specifications; a common approach in business model research (Osterwalder, 2004; Laudien \& Daxböck, 2016a, 2016b). This paper considers only those elements that seem to be of high relevance in the realm of marketplaces. The selection of elements and specifications follows the design principles of morphological analysis. Morphological 
analysis has been identified as a suitable method to gain a holistic understanding of the business model attributes and their specifications within a specific context (e.g. Im \& Cho, 2013; Peters et al., 2015; Pousttchi et al., 2009; Lee et al., 2013). The resulting morphological box can also serve as an artefact to identify innovative business models through new configuration of the attributes' specifications (Kley et al., 2011). The process of morphological analysis followed an iterative process of reviewing the literature on business models, platforms and marketplaces, exploratory expert interviews and its evaluation through coding and confirmatory expert interviews. Table 1 gives an overview of the selected business model attributes that are derived from a review of the literature on business models, platforms and marketplaces and has been refined in several iterations. The first six attributes are part of the value proposition \& delivery dimension (value proposition, product/ service, target customers), the subsequent four are part of the value creation model (key resources and activities), and the final four represent the value capture dimension (revenue and pricing model).

The value creation dimension refers to the firm's value architecture and mechanisms that allow for creating the value proposition. They are expressed in the firm's orchestration of resources and processes (Johnson et al., 2008). For marketplaces, relevant business model attributes relate primarily to the core functions of marketplaces: creating trust and helping participants discover an acceptable price for their transactions partners (Bakos, 1998). Price discovery mechanisms can build on a pricing system in which (a) the platform provider, (b) the supply side or (c) the demand side sets the price. Alternatively, the price discovery can result from competitive pricing mechanisms such as an auction system (Bakos, 1998). Marketplaces primarily create trust by providing reviews of participants' prior transactions (Pavlou \& Dimoka, 2006). Hence, the framework distinguishes whether participants mutually review each other, whether the platform provides a review based on standardized metrics, or whether none of these mechanisms is in place. Further, the framework includes the main type of platform technology (purely web-based or mobile app). When the digital platform serves as a delivery channel for the firm's value proposition, it could also be seen as part of the value proposition \& delivery dimension (e.g. Osterwalder, 2004). However, as the platform technology often presents the key resource of marketplaces, we consider it as part of the firm's value creation dimension. Finally, the firm's key activity can be distinguished between data services, community building, or content creation and curation (Choudary, 2015). Data services refer to the analysis and visualization of transaction data for sellers, among others. Content creation and curation encompasses activities such as co-designing a seller's profile, taking or improving pictures of listings, or active selection of listings. 
Table 1: Key business model attributes of marketplaces

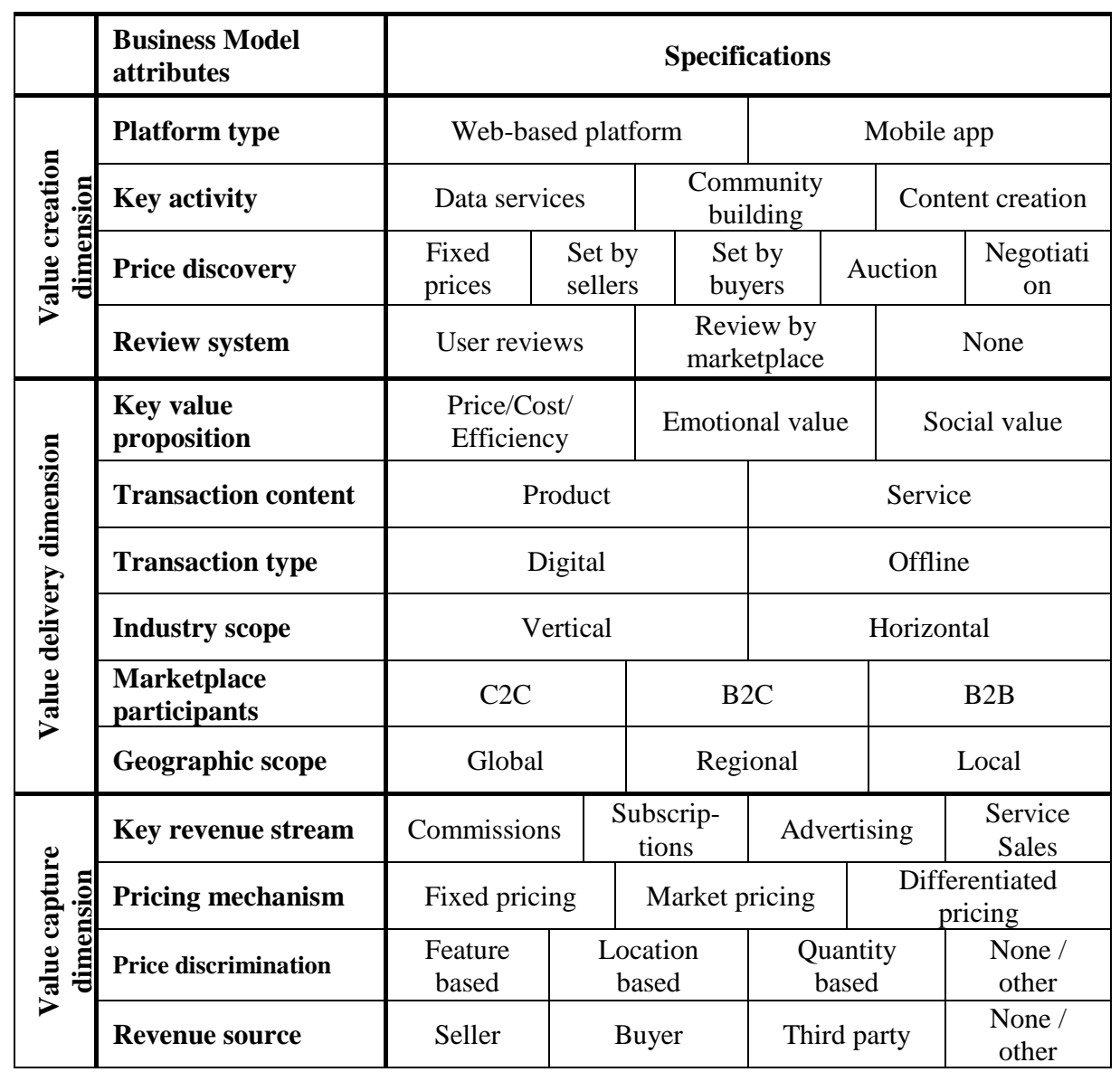

The value delivery dimension contains the elements that generate value for a group of defined target customers. To empirically categorize the value proposition, the framework distinguishes between three types of perceived value: (a) utilitarian value through price, cost, or efficiency advantages, (b) emotional value through superior user experience or the associated image with using the marketplace and (c) social value through the interaction with other marketplace participants. The delivered value further depends on the transaction type (digital vs. offline) and transaction content (product vs. service) (Wirtz, 2015). The combination of these two attributes defines whether the marketplace offers physical products (e.g. used household products), digital products (e.g. digital music), online services (e.g., online tutoring), or offline services (e.g. transportation services). For marketplaces, the dimension should further specify whether the marketplace provides vertical or horizontal market integration (Dai \& Kauffman, 2001), the geographic scope (Schief et al., 2013), and the type of user segments that the marketplace primarily connects as participants (Consumer-to-consumer; Business-to-Consumer, Business-to-Business).

The value capture dimension or profit formula (Baden-Fuller \& Mangematin, 2013) describes how the firm transforms the value delivered to customers into revenues and profits (Teece, 2010; Abdelkafi \& Täuscher, 2016). For marketplaces, revenue stream options can be distinguished between commission model, subscription model, 
advertising model and service sales (Schlie et al., 2011). The pricing model is characterized by fixed pricing, market pricing and differentiated pricing as well as the basis for discriminating between different user groups (e.g. featurebased for premium services) (options derived from Osterwalder, 2004). For marketplaces, the business model is further defined by the decision to monetize supply-side participants, demand-side participants, or a third party (Täuscher \& Chafac, 2016). Since we focus on start-ups, we further include the option 'none' if the firm has not yet started to monetize its services.

\section{Methodology}

To gain deep insights into this topic, we decided for applying a mixed methods approach (Tashakkori \& Teddlie, 2003). A mixed methods approach considerably differs from solely qualitative or quantitative research approaches as it combines both ways of proceeding and incorporates a unique set of ideas and practices (Creswell \& Plano Clark, 2007; Denscombe, 2008; Creswell, 2014). Such an approach is especially beneficial in terms of increased data accuracy and allows for creating a more holistic picture on a new phenomenon by combining strengths of different research methods (Collins et al., 2006). Achieving these benefits calls for applying specific principles. First, a mixed methods approach combines a utilization of qualitative and quantitative methods within the same research project. Second, the sequencing of qualitative and quantitative research elements is clearly defined and the way in which data triangulation takes place is explicitly highlighted (Denscombe, 2008).

Our sampling follows the approach by Hartmann et al. (2014). Firms are drawn from the database AngelList (www.angellist.com/ marketplaces), a network of entrepreneurial ventures. The database provides firms with the possibility to create a profile on its website to increase visibility to investors, potential employees and other stakeholders of interest. While we are interested in marketplace business models rather than any organizational type applying them, the empirical focus on entrepreneurial ventures allows for better isolation of the phenomenon of interest. Entrepreneurial ventures are suited for analyzing and clustering business models since they generally apply only one business model. In contrast, larger firms often manage a portfolio of several business models (Sabatier et al., 2010). Our sample consists of those ventures that are categorized as 'marketplaces' on the AngelList database. We randomized the list of ventures using the service random.org, which generates randomness via atmospheric noise. The first 100 ventures from the randomized list were selected as the study sample. Within the process of analyzing their business models, we had to exclude a total of 69 ventures which do not meet the applied definition of marketplaces (e.g. retailer) or did not provide sufficient information for the defined business model attributes. For every excluded venture, the subsequent one from the randomized list was added to the sample.

Obtaining reliable data for entrepreneurial ventures is a difficult undertaking. The developed framework and questions require some knowledge about the underlying definitions to allow for consistency within the dataset. Therefore, we chose to collect data ourselves based on secondary sources. This approach follows prior empirical research on business models (Zott \& Amit, 2008). Data was selected from the firm`s websites, online databases, as well as online articles of newspapers and journals. If the business model changed over time, we used the most up- 
to-date information and did not consider a previous business model. Prior research has shown that this methodology is valid for analyzing business models of entrepreneurial ventures (Hartmann et al., 2014). In total, we identified, collected, and analyzed 460 different documents between July and September 2015.

In this study, we started off with a qualitative content analysis and codified the observations with regard to the selected variables (see section 2). We represented each of the specifications from table 1 as a binary variable to assess whether the specification is part of the respective firm's business model. Two independent coders knowledgeable about the topics manually examined the identified documents for statements regarding particular attributes of the framework. We used MaxQDA 11 for the documentation of the coding process and the retrieval of codings afterwards. While specifications for most attributes are mutually exclusive and unambiguous, it was not always possible to determine the key value proposition and key activity. In these cases, we coded each specification independently, which led for some firms to none or more than one positively coded variable for the attribute. After coding all documents about a marketplace firm, we reviewed the information for the categories. If there was information missing about a variable, the existing documents were specifically scanned for such information and if necessary - supplemented by additional sources. The output of the coding process is a database of business modelrelated text passages and the binary variable values for 100 marketplace firms.

In a second step, we made use of a quantitative approach and analyzed the hand-collected data with different cluster analysis techniques. Cluster analysis aims at discovering distribution patterns and identifying interesting correlations among data attributes. The methodology also supports discovering ideal types of a similar group of objects (Ketchen \& Shook, 1996). First, we focused on identifying the number of clusters (i.e. different marketplace business model types). Following Ketchen and Shook (1996), we used hierarchical clustering (agglomerative hierarchical clustering) as well as visual examination of the dendrogram to determine the number of clusters. The agglomerative hierarchical clustering analysis included an initial set of 82 binary variables (some variables have been eliminated afterwards due to poor discriminatory power or variable relevance). We chose a method that aims at maximizing the homogeneity within the clusters, applying an Euclidian scale to measure the distance.

To identify the six clusters, we followed the recommendation by Ketchen and Shook (1996) and apply a nonhierarchical clustering process. Nonhierarchical clustering partitions a data set into a predefined number of clusters, aiming at generating optimized solutions. Contrary to the hierarchical methods, clusters are rearranged during the process. We used the nonhierarchical method of $\mathrm{k}$-means that partitions the $\mathrm{n}$ observations into $\mathrm{k}$ clusters in which each observation belongs to the cluster with the nearest mean. The center of each of the k clusters can subsequently be interpreted as an ideal type of the cluster. To discover and select the limited set of variables for kmeans clustering, we combined an analytical with an experimental approach. Researchers should select only those variables for clustering that are believed to help determine the underlying clustering in the data (Milligan, 1995). Based on the predefined number of clusters and the selected variables, we then conducted a partitioning k-means cluster analysis. 


\section{Sample characteristics and key clustering variables}

The 100 firms are equally distributed over several industries with the largest shares in hospitality (13\%), delivery and professional services (12\%), industrial goods (11\%), consumer goods (10\%), and education (9\%). From the 100 marketplaces in the sample, 90 count less than 50 employees. Half of the firms consist of less than ten employees. Most of the firms were founded between 2010 and 2013, with only 15 firms founded before 2010 and 13 founded after 2013. The sample contains an almost equal amount of marketplaces for physical products (28), offline services (28) and digital services (30), with a high share of offline services founded after the year 2010. In comparison, marketplaces for digital products represent a small group, with the oldest of these founded in 2011.

The key value proposition of the marketplaces is relatively concentrated: $75 \%$ of the firms in the sample provide value through increased efficiency or cost savings. Regarding the marketplace participants, only eight marketplaces match businesses with each other (B2B). This is in line with our definition of marketplaces that excludes highly automated and standardized commodity trading (e.g. stock markets). The majority of sample firms (60\%) match individual buyers and sellers with each other (C2C). In half of these $\mathrm{C} 2 \mathrm{C}$ marketplaces, customer segments can overlap; a customer can simultaneously act as seller and buyer. One third of marketplaces matches businesses with consumers (B2C).

Table 2: Revenue sources and streams of marketplaces

\begin{tabular}{|c|c|c|c|c|c|c|c|}
\hline & & \multicolumn{5}{|c|}{ Demand side } & \multirow{2}{*}{ Total } \\
\hline & & \multicolumn{2}{|c|}{$\begin{array}{l}\text { Commissi } \\
\text { on }\end{array}$} & \multirow{2}{*}{$\begin{array}{c}\begin{array}{c}\text { Subscri- } \\
\text { ption }\end{array} \\
1\end{array}$} & \multicolumn{2}{|c|}{ Free } & \\
\hline \multirow{4}{*}{$\begin{array}{l}\text { Supply } \\
\text { side }\end{array}$} & $\begin{array}{c}\text { Commissi } \\
\text { on }\end{array}$ & 9 & \multirow{2}{*}{1} & & 48 & \multirow{2}{*}{4} & 60 \\
\hline & $\begin{array}{l}\text { Subscri- } \\
\text { ption }\end{array}$ & 0 & & 2 & 5 & & 10 \\
\hline & Free & \multicolumn{2}{|c|}{12} & 1 & \multicolumn{2}{|c|}{12} & 25 \\
\hline & Total & \multicolumn{2}{|c|}{22} & 4 & \multicolumn{2}{|c|}{69} & 95 \\
\hline
\end{tabular}

$* \mathrm{n}=95$; information for these attributes was not available for 5 sample firms

The variables from the value capture dimension show that $72 \%$ of marketplaces generate revenues from commission fees. Another $22 \%$ generate subscription fees, while listing/bidding fees (3\%) and advertising (2\%) are the exception. Ten of the sample firms combine a commission fee with a subscription or listing/bidding fee. Yet, $9 \%$ of the analyzed firms have no visible revenue streams at this point. Table 2 gives an overview of the observed combinations from the view of both the demand and supply side (commission fee, subscription fee, or no fee) Breaking down the revenue stream by user segment, commissions are the primary option for $\mathrm{C} 2 \mathrm{C}(79 \%)$ and $\mathrm{B} 2 \mathrm{C}$ (70\%) marketplaces. B2B marketplaces focus less on commissions (33\%) and more on subscriptions (66\%). While 
these descriptive statistics are not statistically significant, they serve as an indication for the population of marketplaces in general.

Regarding the value creation elements, the majority of firms provides some form of review system. The data suggests that a review system is much more common in service marketplaces $(74 \%)$ than in product marketplaces $(40 \%)$. Marketplaces in the areas of education, design services and home services have the highest share of review systems. In around $80 \%$ of the cases, the review system allows only the buyer side to assess the seller side. Reviews by the marketplace provider (14\%) are rather the exception. Marketplaces generally create value by supporting the price selection process. In $68 \%$ of the sample firms the seller side is responsible for price setting. In the remaining marketplaces, the platform provider determines the price in 15 cases, the price is determined through negotiation (8), an auction (7), and / or buyers determine the price (4).

The first clustering phase and conceptual considerations have revealed the key variables for the further clustering process. These variables are based on the specifications for five different business model attributes presented in table 1: (1) transaction content (product; service), (2) transaction type (digital; offline), (3) marketplace participants (C2C; B2C; B2B), (4) key activity (community building), and (5) revenue source (buyers; suppliers). It is noteworthy that we focus only on specifications that seem to provide high discriminatory power and that allow some form of interpretation. While some firms did neither monetize buyers or sellers, it was in some cases not clear whether they generated revenues from a third party (e.g. advertisers) or had no significant revenue source at all. Also, for the attribute of 'key activity', the specification of 'community building' proved to provide a high reliability in the coding process as well as a good discriminatory power. Since the specification contains the information whether the firm focuses on building an active community of users, the variable was consistently assessed by studying the platform's social network functions. For the specifications of transaction content, transaction type and marketplace participants, only the dominant option was chosen. Hence, these attributes can each be considered as one independent variable instead of two or three. In total, the iterative clustering process allowed identifying 6 independent variables.

\section{Classification of marketplace business models}

The attributes identified with strong discriminatory power are subsequently used to determine the clusters. Visual examination of the dendrogram of the agglomerative hierarchical clustering suggests a solution with six clusters. In the clustering solution, each of the 100 firms belongs to one of the clusters, with only eight of them showing a distance higher than 1.3 from the cluster center. Table 3 lists the cluster centers for each of them in regards to the selected attributes. Subsequently, we tested the robustness and stability of the six-cluster solution by selecting different clustering algorithms and variable combinations based on recommendations by Leask and Parker (2007). One variable combination (omitting marketplace participants and key activity) led to a solution with seven clusters. In this case, however, one cluster consisted of only 6 firm cases who did not allow for meaningful interpretation. An additional elbow test (see Milligan, 1995) further confirmed that no other number of clusters was clearly preferable 
to the six cluster solution. Finally, we confirmed the relevance of the clustering solution by interpreting each of the clusters. For each cluster, we conducted a mini case study of a representative firm and reviewed descriptive statistics for the group of firms. In each case, the statistics provided a meaningful interpretation that was in line with the business model of the case firm.

We can primarily characterize the six clusters by analyzing their technical centers. It becomes apparent that there is an even split between product-focused and service-focused business models. Two clusters focus on digitally delivered transactions, while four clusters contain marketplaces for products that are delivered physically. As a consequence, each cluster can clearly be related to one type of transaction content: 1 and 3 center on physical products, cluster 2 focuses on transactions of digital products, 4 and 6 on offline services and 5 on online services.

Table 3: Technical Cluster Center of k-means analysis with six independent variables

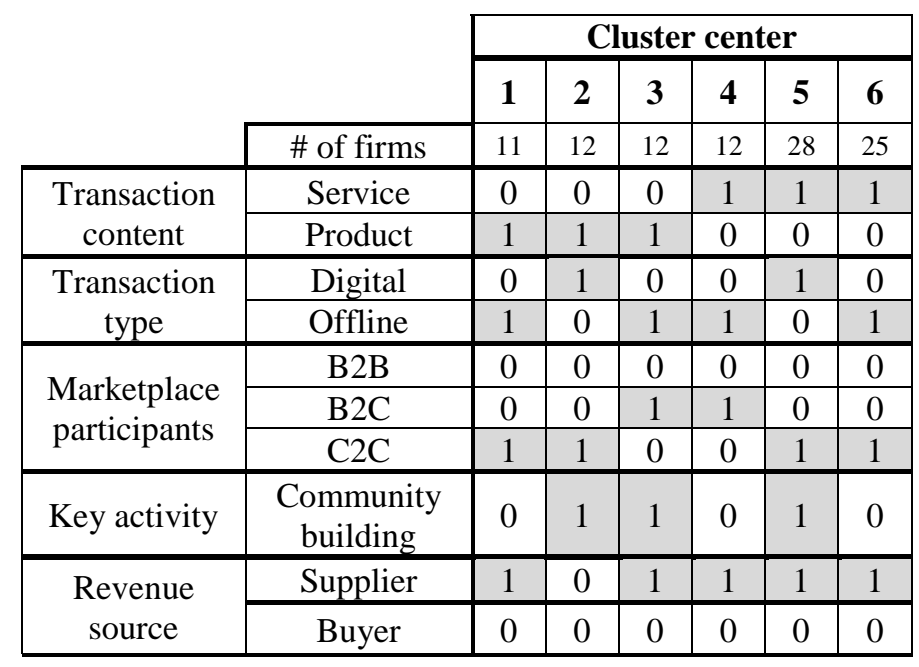

The variable marketplace participants also contributes strongly to the cluster formation. Interestingly, all cluster centers are either located on B2C ( $3 \& 4)$ or C2C transactions. These technical cluster centers give a good idea of the general characteristics of firms in the cluster. Nevertheless, this does not mean that all firms of the cluster fulfill the particular attribute. To reveal the core differences between the six clusters, figure 2 represents them as a matrix with the combined transaction content and type on one axis and the type of marketplace participants on the other axis. In the representation, the technical center of each cluster is displayed with one color. The shadow of the same color represents the spread of different forms in that cluster. For instance, cluster five technically represents $\mathrm{C} 2 \mathrm{C}$ online services. However, the cluster also contains firms that provide online services for B2C and B2B customers. It becomes apparent that clusters 1, 2 and 3 partly overlap regarding these two dimensions. 
Figure 2: Clusters plotted against transaction content and type (combined) and marketplace participants

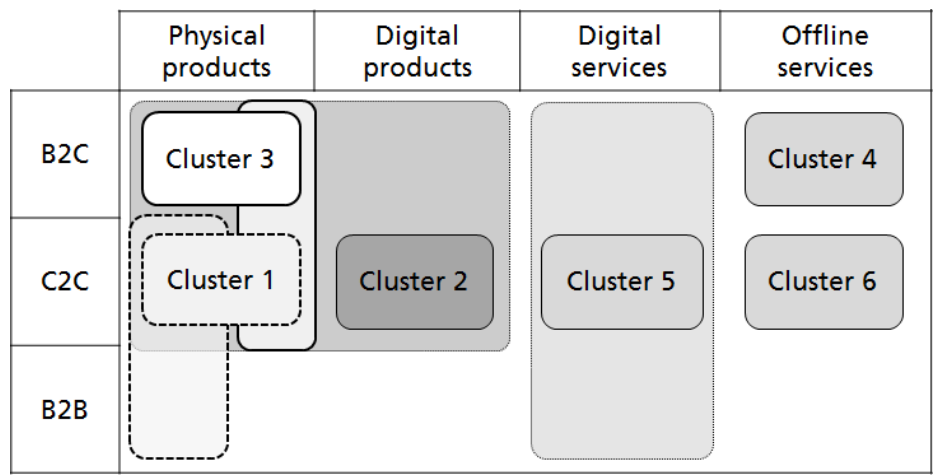

The key activity of community building is another variable with important impact on the cluster formation. Contrary to the remaining four clusters, the large majority of firms in cluster 2 and 3 strongly focus on communitybuilding activities. Surprisingly, the clustering process did not use the revenue source as a discriminator. Here, all but cluster 2 center around the same option: only the seller pays for the service. While the center of cluster 2 suggests that firms in this cluster do not charge any market side, the detailed analysis reveals that these firms are evenly spread between several revenue sources (including third parties). In fact, only one firm in cluster 2 does not use any visible source of revenue at all.

Table 4: Business model elements for the value creation dimension. All values in percent of total firms in cluster.

\begin{tabular}{|c|c|c|c|c|c|c|c|}
\hline \multirow{2}{*}{\multicolumn{2}{|c|}{$\begin{array}{c}\text { Business model } \\
\text { attributes and } \\
\text { specifications }\end{array}$}} & \multicolumn{6}{|c|}{ Cluster } \\
\hline & & \multirow{2}{*}{$\frac{\mathbf{1}}{.36}$} & \multirow{2}{*}{$\frac{2}{.25}$} & \multirow{2}{*}{$\frac{3}{.50}$} & \multirow{2}{*}{$\begin{array}{c}\mathbf{4} \\
.58\end{array}$} & \multirow{2}{*}{$\frac{5}{.25}$} & \multirow{2}{*}{$\begin{array}{c}\mathbf{6} \\
.48\end{array}$} \\
\hline & Mobile app & & & & & & \\
\hline$\frac{\bar{t}}{2} \Xi$ & $\begin{array}{l}\text { Pure web } \\
\text { platform }\end{array}$ & .64 & .75 & .50 & .42 & .75 & .52 \\
\hline \multirow{3}{*}{ 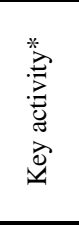 } & $\begin{array}{c}\text { Data } \\
\text { services }\end{array}$ & .45 & .25 & .17 & .75 & .39 & .28 \\
\hline & $\begin{array}{c}\text { Community } \\
\text { building }\end{array}$ & .09 & .75 & .58 & .08 & .57 & .12 \\
\hline & $\begin{array}{l}\text { Content } \\
\text { creation }\end{array}$ & 0 & .17 & .25 & .08 & .11 & .04 \\
\hline \multirow{5}{*}{ 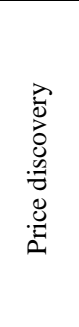 } & Set by seller & .50 & .55 & .85 & .67 & .64 & .73 \\
\hline & Set by buyer & 0 & .18 & .08 & 0 & .04 & 0 \\
\hline & $\begin{array}{l}\text { Fixed (by } \\
\text { platform) }\end{array}$ & .08 & .18 & 0 & .17 & .21 & .15 \\
\hline & Auction & .25 & .09 & 0 & .08 & .04 & .08 \\
\hline & Negotiation & .17 & 0 & .08 & .08 & .07 & .04 \\
\hline \multirow{3}{*}{ 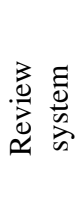 } & $\begin{array}{c}\text { User } \\
\text { reviews }\end{array}$ & .55 & .25 & .33 & .58 & .50 & .64 \\
\hline & $\begin{array}{l}\text { Review by } \\
\text { platform }\end{array}$ & .27 & 0 & 0 & 0 & .11 & .08 \\
\hline & None & .27 & .75 & .67 & .42 & .39 & .28 \\
\hline
\end{tabular}

* More than one option possible 
To interpret the six clusters, we analyzed the characteristics of each business model type quantitatively by analyzing the marketplace firms included in the corresponding cluster. The descriptive statistics are provided as an average of all firms for each of the clusters in table 4 (value creation), 5 (value delivery), and 6 (value capture). The first column of these tables represents the 14 business model attribute as identified in table 1 . The second column represents the specifications of these attributes. Out of the original 43 specifications, we excluded two variables from the analysis due to difficulties in assessing them reliably: service sales (key revenue stream), and none (price discrimination). Since it was not always possible to identify the key revenue stream and the price discrimination system, we provide a variable with a combined value for none or other. In the case of revenue streams, the variable contains those firms that primarily use service sales. At the same time, we added the variable of hybrid for the revenue source attribute to represent when firms applied more than one dominant revenue source. In addition, we combined transaction content and transaction type as in figure 2. The subsequent columns represent the percentage of firms in the cluster in which the specific variable is positive. In cluster 1, for instance, $91 \%$ of firms offer the key value proposition of a price, cost or efficiency advantage and $100 \%$ of firms offer physical goods. All percentage values are rounded; therefore, they do not necessarily add up to $100 \%$. Please note that the quantitative data on the percentage distribution of the business model attributes is only indicative but not statistically significant given the small sample size. 
Table 5: Distribution of cluster firms for value delivery dimension.

\begin{tabular}{|c|c|c|c|c|c|c|c|}
\hline \multirow{2}{*}{\multicolumn{2}{|c|}{$\begin{array}{l}\text { Business model } \\
\text { attributes \& } \\
\text { specifications }\end{array}$}} & \multicolumn{6}{|c|}{ Cluster } \\
\hline & & \multirow{2}{*}{$\begin{array}{l}\mathbf{1} \\
.91\end{array}$} & \multirow{2}{*}{$\frac{2}{.58}$} & \multirow{2}{*}{$\frac{3}{.42}$} & \multirow{2}{*}{$\frac{4}{.83}$} & \multirow{2}{*}{$\begin{array}{l}\mathbf{5} \\
.75\end{array}$} & \multirow{2}{*}{$\frac{6}{.88}$} \\
\hline \multirow{3}{*}{ 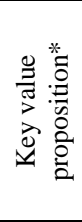 } & $\begin{array}{l}\text { Price/ cost / } \\
\text { efficiency }\end{array}$ & & & & & & \\
\hline & $\begin{array}{c}\text { Emotional } \\
\text { value }\end{array}$ & 0 & .33 & .67 & .33 & .29 & .28 \\
\hline & $\begin{array}{c}\text { Social } \\
\text { value }\end{array}$ & .09 & .67 & .50 & 0 & .57 & .08 \\
\hline \multirow{4}{*}{ 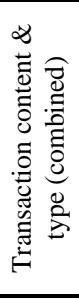 } & $\begin{array}{l}\text { Physical } \\
\text { products }\end{array}$ & 1 & .33 & 1 & 0 & 0 & 0 \\
\hline & $\begin{array}{l}\text { Digital } \\
\text { products }\end{array}$ & 0 & .67 & 0 & 0 & 0 & 0 \\
\hline & $\begin{array}{l}\text { Online } \\
\text { services }\end{array}$ & 0 & 0 & 0 & 0 & .97 & 0 \\
\hline & $\begin{array}{c}\text { Offline } \\
\text { services }\end{array}$ & 0 & 0 & 0 & 1 & .03 & 1 \\
\hline \multirow{3}{*}{ 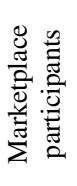 } & $\mathrm{C} 2 \mathrm{C}$ & .63 & .83 & .33 & 0 & .57 & 1 \\
\hline & B2C & 0 & .17 & .67 & .92 & .32 & 0 \\
\hline & B2B & .36 & 0 & 0 & .08 & .11 & 0 \\
\hline \multirow{2}{*}{ 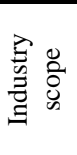 } & $\begin{array}{c}\text { Vertical } \\
\text { integration }\end{array}$ & .64 & .67 & .67 & .75 & .75 & .80 \\
\hline & $\begin{array}{l}\text { Horizontal } \\
\text { integration }\end{array}$ & .36 & .33 & .33 & .25 & .25 & .20 \\
\hline \multirow{3}{*}{ 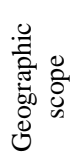 } & Local & .72 & .33 & .42 & .67 & .54 & .80 \\
\hline & Regional & 0 & .25 & .08 & .25 & .07 & .00 \\
\hline & Global & .27 & .42 & .50 & .08 & .39 & .20 \\
\hline
\end{tabular}

* More than one option possible

Cluster 1 consists of marketplaces for physical products. Two thirds of the firms facilitate transactions between individuals (C2C), while one third facilitates transactions between businesses. The majority (64\%) of the marketplaces in this cluster exchange industrial goods. Therefore, these marketplaces often aim at standardizing and commoditizing products to facilitate search and negotiation. For the individual sellers, the platform offers access to a large market of potential buyers. 91\% of the sample firms in this cluster use the platform primarily for superior efficiency and prices. Two thirds of firms generate revenues from commissions; one fourth also generates revenues from subscriptions. These subscriptions are often charged to the seller side for additional services, increased visibility or access to customer data. In particular, all subscription models are offered with different price options in relation to the included service features. An example for a firm in this cluster is Beepi, a start-up offering a marketplace for used cars. Based on the cluster characteristics, we label the related business model type as 'efficient product transactions'. 
Table 6: Business model elements for value capture dimension

\begin{tabular}{|c|c|c|c|c|c|c|c|}
\hline \multirow{2}{*}{\multicolumn{2}{|c|}{$\begin{array}{l}\text { Business model } \\
\text { attributes and } \\
\text { specifications }\end{array}$}} & \multicolumn{6}{|c|}{ Cluster } \\
\hline & & \multirow{2}{*}{$\frac{1}{64}$} & \multirow{2}{*}{$\frac{2}{.69}$} & \multirow{2}{*}{3} & \multirow{2}{*}{$\begin{array}{c}\mathbf{4} \\
.57\end{array}$} & \multirow{2}{*}{$\frac{5}{.55}$} & \multirow{2}{*}{$\begin{array}{c}\mathbf{6} \\
.80\end{array}$} \\
\hline \multirow{4}{*}{ 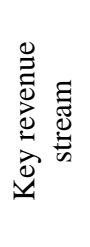 } & Commissions & & & & & & \\
\hline & Subscriptions & .27 & 0 & .15 & .36 & .28 & .16 \\
\hline & Advertising & 0 & 0 & .08 & 0 & .03 & 0 \\
\hline & None / other & .09 & .31 & 0 & .07 & .14 & 4 \\
\hline \multirow{3}{*}{ 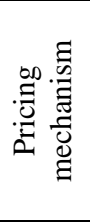 } & $\begin{array}{l}\text { Fixed } \\
\text { pricing }\end{array}$ & .50 & .50 & .89 & .42 & .46 & .62 \\
\hline & $\begin{array}{l}\text { Market } \\
\text { pricing }\end{array}$ & 0 & 0 & 0 & 0 & 0 & .05 \\
\hline & $\begin{array}{l}\text { Differentia- } \\
\text { ted pricing }\end{array}$ & .50 & .25 & .11 & .50 & .42 & .29 \\
\hline \multirow{4}{*}{ 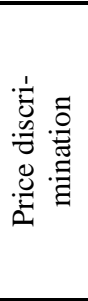 } & $\begin{array}{c}\text { Feature } \\
\text { based }\end{array}$ & .60 & 0 & 0 & .50 & .36 & .33 \\
\hline & $\begin{array}{c}\text { Geography } \\
\text { based }\end{array}$ & 0 & 0 & 0 & .17 & 0 & 0 \\
\hline & $\begin{array}{c}\text { Quantity } \\
\text { based }\end{array}$ & 0 & .67 & 0 & 0 & .45 & .33 \\
\hline & $\begin{array}{c}\begin{array}{c}\text { None / } \\
\text { other }\end{array} \\
\end{array}$ & .40 & .33 & 1 & .33 & .81 & .34 \\
\hline \multirow{5}{*}{ 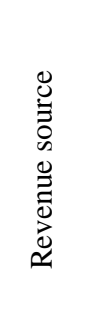 } & Seller & .88 & .33 & 1 & .73 & .68 & .55 \\
\hline & Buyer & 0 & .25 & 0 & .09 & .08 & .30 \\
\hline & Hybrid & .13 & .17 & 0 & .09 & .12 & .10 \\
\hline & Third party & 0 & .17 & 0 & 0 & 0 & .0 \\
\hline & None (Free) & 0 & .08 & 0 & .09 & .12 & .05 \\
\hline
\end{tabular}

The second cluster contains start-ups that primarily build a community around products. It contains $100 \%$ of digital product marketplaces which represent two thirds of the cluster's firms. The remaining third are physical product exchanges. The marketplace primarily creates value to users by developing an active community of likeminded people (67\%). Therefore, the related BM type can be described as 'digital product community'. While most of the transactions take place between individuals (83\%), $17 \%$ of the cluster firms apply a B2C model. In most cases, the marketplace charges a commission fees as primary revenue (69\%). Given the low geographic boundaries of digital goods, this cluster has the highest share of globally operating marketplaces. Interestingly, this cluster contains the highest share of marketplaces in which buyers can set prices. Based on its dominant variable, we label the cluster 'product community'. For instance, the self-publishing platform Sellfy enables creators of a variety of digital content - from e-books, music, videos to software - to commercialize their content via the platform. The platform has built a community of independent authors, musicians and designers that maintain active social network profiles on the marketplace site and interact directly with buyers. 
The third cluster consists entirely of marketplaces that facilitate the exchange of physical products. Two thirds of the firms focus on $\mathrm{B} 2 \mathrm{C}$, one third on $\mathrm{C} 2 \mathrm{C}$ transactions. A large share of marketplaces in this cluster creates emotional value through the image of the platform (67\%). Also, the community aspect of these business models is much higher than in cluster 1 - the other cluster of physical products. All firms charge the seller side; either with a commission (77\%) and/or subscription model (15\%). Sellers set fixed prices for the products they sell (85\%), but have to accept fixed fees from the marketplace. Firms in the cluster tend to apply a vertical model to concentrate on one distinctive product category (67\%). While start-ups in this cluster focus the least on data-activities (17\%), they are the most active cluster in creating and curating the product listings. We label the cluster as 'product aficionados' since firms using this BM type tend to build a community of people with a shared passion for a certain product type. Such users are drawn to the community to discuss these products and inform themselves. Examples include aficionados of independent art products (artsy), handmade design (solidarum), educational products (educents), independent music (merchbar), or collectibles (hobbyDB).

Cluster 4 comprises marketplaces that match service firms with consumers. The exchanged services are delivered through offline channels and therefore require some form of scheduling. The primary value for both the businesses offering the services and their customers relates to efficiency gains (83\%). Within the cluster, firms can be subdivided into two groups. A first group of firms acts as aggregators for services that require an appointment. Examples include hairdressers (styleseat), car rides (technorides), or touristic activities (gidsy, headout). The second type is not based on appointments, but some other form of capacity management. Examples include services for shipping (shyp), alcohol delivery (drizly) or construction work (buildzoom). The firms in this cluster often the highest share of mobile apps. Firms primarily charge a commission fee from sellers (73\%), while buyers mostly use the marketplace for free. Given the location dependence, most firms focus on one geographic market and one market segment. The cluster has the highest percentage of firms that provide reviews of sellers. Based on its time-sensitive nature, we label the business model as 'on-demand offline services'.

Cluster 5 represents the largest cluster, containing $28 \%$ of firms from the entire sample. The cluster is labeled 'online services' since firms offer services that are consumed via a web-based platform. This includes individuals sharing their skills through online language tutoring (italki), teaching classes (skillshare), or video-based online courses (udemy). The cluster also includes marketplaces for professional freelancers such as divorce attorneys (wevorce, breakthrough), municipal financial investors (neighborly), designers (visually), or scientific researchers (experiment). These marketplaces offer the value proposition of additional income (for sellers) and efficient access to services (for buyers). In many cases, the users also perceive a value from the active community around the core service. Generally, these marketplaces focus on one specific market segment. The cluster has the highest share of firms setting a fixed price per service. Hence, firms in this cluster commodify services to a certain extent.

With one fourth of firms assigned to cluster 6 , it represents the second-largest cluster in the sample. The cluster is characterized by peer-to-peer exchange of services in the physical world and is therefore described as 
'Peer-to-peer offline services'. Firms in this cluster can be further divided into two sub-types: (a) individuals sharing their physical resources and (b) individuals providing their time and skills. Resource sharing firms include private accommodation (Airbnb), office space (sharedesk), or cars (getaround). Time- and skill-sharing services comprise pet sitting (spotwag), delivery services (postmates), or event organization (honeybook). As in cluster 5, these firms provide a novel source of income for the supply side and create value to the buyer side through an increase in transaction efficiency (88\%) and a positive platform image (28\%). $72 \%$ of the firms in this cluster provide a review system to generate trust between the users. The revenue streams are predominantly generated from commission fees (80\%), with $60 \%$ of platforms determining a fixed fee. More than half of the firms generate revenue from the seller side, but the share of firms that charge buyers is highest among all clusters.

\section{Discussion and Implications}

\section{Relevance of taxonomy}

The clustering revealed six fundamentally distinctive business model types for marketplaces. Table 7 provides a summary of the business model characteristics of each of these types. It focuses on those business model elements that proved the strongest source of discrimination. In addition, it provides an interpretation of the value propositions, based on the qualitative analysis of firms within each cluster. The overview shows that while type 1 (efficient product transactions) and 3 (product aficionados) both facilitate the commercial exchange of physical products, they are fundamentally different in their value proposition. Type 1 provides superior efficiency and cost advantages to participants. Type 3 provides a social function in which members become primarily part of a community of like-minded people interested in a particular product type. Type 4 (on-demand offline services) and 6 (peer-to-peer offline services) both match supply and demand for real-world services, but their supply-side logic is completely different. Marketplaces with business model type 4 can be interpreted as novel and efficient sales channels for businesses that allow an effective capacity management. In contrast, business models of type 6 often provide entirely novel value propositions to their supply-side. We suggest that firms pioneering these business models in their industry, such as Airbnb, often create entirely new markets based on previously untapped resources. In fact, BM type 6 reveals a strong resemblance with firm characteristics discussed for the so-called sharing economy (Hamari et al., 2016; Sundararajan, 2016). This finding suggests that a marketplace business model perspective might provide a useful lens to overcome the challenges in defining the boundaries of the sharing economy as currently experienced by the related literature (Martin, 2016). 
Table 7: Summary of business model types

\begin{tabular}{|c|c|c|c|c|c|c|}
\hline Dimension & Value Creation & & Value delivery & & Value capture & \\
\hline $\begin{array}{l}\text { Business } \\
\text { model element }\end{array}$ & Platform type & $\begin{array}{c}\text { Platform } \\
\text { participants }\end{array}$ & $\begin{array}{c}\text { Value proposition (to } \\
\text { demand side) }\end{array}$ & $\begin{array}{l}\text { Transaction } \\
\text { type \& good }\end{array}$ & Revenue model & Example \\
\hline $\begin{array}{l}\text { Efficient } \\
\text { product } \\
\text { transactions }\end{array}$ & $\begin{array}{l}\text { Web-based } \\
\text { platform }\end{array}$ & $\mathrm{C} 2 \mathrm{C}, \mathrm{B} 2 \mathrm{~B}$ & $\begin{array}{l}\text { E/CS; large product } \\
\text { variety }\end{array}$ & $\begin{array}{l}\text { Physical } \\
\text { products }\end{array}$ & $\begin{array}{lr}\text { Commission } & \text { fee, } \\
\text { subscription } & \text { fee } \\
\text { (mostly SS) } & \end{array}$ & $\begin{array}{l}\text { Beepi (eBay for } \\
\text { used cars) }\end{array}$ \\
\hline $\begin{array}{l}\text { Digital } \\
\text { product } \\
\text { community }\end{array}$ & $\begin{array}{l}\text { Web-based } \\
\text { platform }\end{array}$ & $\mathrm{C} 2 \mathrm{C}$ & $\begin{array}{l}\mathrm{SV}, \mathrm{EV}, \mathrm{E} / \mathrm{CS} \text {; being } \\
\text { part of a primary non- } \\
\text { commercial community }\end{array}$ & $\begin{array}{l}\text { Digital products; } \\
\text { physical } \\
\text { products }\end{array}$ & $\begin{array}{lr}\text { Commission } & \text { fee; } \\
\text { supply } & \text { side, } \\
\text { demand side } & \end{array}$ & $\begin{array}{l}\text { Sellfy (connecting } \\
\text { 'neighbors' to } \\
\text { share durable } \\
\text { goods with each } \\
\text { other) }\end{array}$ \\
\hline $\begin{array}{l}\text { Product } \\
\text { aficionados }\end{array}$ & $\begin{array}{l}\text { Web-based \& } \\
\text { mobile platform }\end{array}$ & $\mathrm{B} 2 \mathrm{C}, \mathrm{C} 2 \mathrm{C}$ & $\begin{array}{l}\text { EV, SV, E/CS; } \\
\text { exchanging knowledge } \\
\text { about niche products } \\
\text { with community of like- } \\
\text { minded people }\end{array}$ & $\begin{array}{l}\text { Physical } \\
\text { products }\end{array}$ & $\begin{array}{l}\text { Commission fee; } \\
\text { supply side }\end{array}$ & $\begin{array}{l}\text { hobbyDB ("eBay } \\
\text { meets IMDB/ } \\
\text { Wikipedia" for } \\
\text { hobbies } \\
\text { collectibles) }\end{array}$ \\
\hline $\begin{array}{l}\text { On-demand } \\
\text { offline services }\end{array}$ & $\begin{array}{l}\text { Web-based \& } \\
\text { mobile platform }\end{array}$ & B2C & $\begin{array}{l}\text { E/CS; accessing large } \\
\text { service variety in a } \\
\text { novel form }\end{array}$ & Offline services & $\begin{array}{l}\text { Commission fee, } \\
\text { subscription fee; } \\
\text { mostly supply side }\end{array}$ & $\begin{array}{l}\text { StyleSeat } \\
\text { (connecting } \\
\text { beauty salons \& } \\
\text { consumers) }\end{array}$ \\
\hline $\begin{array}{l}\text { Online } \\
\text { services }\end{array}$ & $\begin{array}{l}\text { Web-based } \\
\text { platform }\end{array}$ & $\mathrm{C} 2 \mathrm{C}, \mathrm{B} 2 \mathrm{C}$ & $\begin{array}{llr}\text { E/CS, EV; } & \text { SV; } \\
\text { providing } & \text { novel } & \text { online } \\
\text { services with social } \\
\text { networking }\end{array}$ & Online services & $\begin{array}{l}\text { Commission fee, } \\
\text { subscription fee; } \\
\text { mostly supply side }\end{array}$ & $\begin{array}{l}\text { iTalki } \\
\text { (connecting } \\
\text { language learners } \\
\text { with teachers for } \\
\text { 1-on-1 online } \\
\text { lessons) }\end{array}$ \\
\hline $\begin{array}{l}\text { Peer-to-peer } \\
\text { offline services }\end{array}$ & $\begin{array}{l}\text { Web-based \& } \\
\text { mobile platform }\end{array}$ & $\mathrm{C} 2 \mathrm{C}$ & $\begin{array}{l}\text { E/CS, EV; providing } \\
\text { novel services with } \\
\text { community feeling } \\
\text { within \& outside digital } \\
\text { platform }\end{array}$ & Offline services & $\begin{array}{l}\text { Commission fee } \\
\text { (demand \& supply } \\
\text { side), subscription } \\
\text { fee (third parties) }\end{array}$ & $\begin{array}{l}\text { Airbnb } \\
\text { (connecting } \\
\text { people to list, } \\
\text { discover, and } \\
\text { book private } \\
\text { accommodations) }\end{array}$ \\
\hline
\end{tabular}

Identifying these types of competing value propositions allows for a better understanding of a marketplace's competitors and market potential. Reviewing the 4-digit SIC codes for the selected 100 marketplaces revealed the challenges of assigning them to traditional industry classifications. Following the SIC codes, these marketplaces are classified according to the industry they operate in (e.g. 'Museums and Art Galleries'), focus on the digital platform of their core product (e.g. 'Computer Programming Services', 'Information Retrieval Services') or consider them as miscellaneous services (e.g. 'Business services, other'). Such a classification is limited in estimating a marketplace's market potential and has led to highly opposing views on the commercial potential of marketplaces like Uber (Gurley, 2015). Recognizing that marketplaces offer social and emotional value to participants (mostly type 2 and 3) can help understand the market they operate in. Such a value proposition-centered perspective has therefore important implications for investors and managers in evaluating the growth and profit potential of these ventures and developing competitive strategies and novel marketplace business models. Rooted in these different value propositions to the demand- and supply side, certain business model choices seem to be direct consequences and might have important implications on marketplace pricing, design, or management.

\section{Contribution to literature}

The taxonomy and empirical findings contribute to the broader discussion on marketplaces. Within this research stream, it complements former studies focused on electronic marketplaces and e-marketplaces (Ordanini \& 
Pol, 2001; Brunn et al., 2002; Bakos, 1998; Engström \& Salehi-Sangari, 2007; Giaglis et al., 2002). While the studies on electronic marketplaces are primarily interested in business-to-business marketplaces that facilitate sourcing and procurement, this research presents a much broader array of marketplace functions and types. In fact, the business models discussed by previous marketplace literature primarily relate to BM type 1 in our taxonomy (efficient product transactions). This research therefore provides an updated and expanded perspective on marketplaces, integrating novel business model types that only became possible through recent technological advances (Täuscher, 2016). Besides the broader scope, the taxonomy goes beyond previous marketplace classifications (Kaplan \& Sawhney, 1999; Lavassani et al., 2011; Balocco et al., 2010) in that it applies a rigorous mixed methods approach. While the identified elements of transaction channel and marketplace participants are consistent with prior literature, the mixed methods approach allowed integrating multiple dimensions into the taxonomy design. For instance, whether the firm actively focuses on community building seems to represent an important factor for business model distinction that has multiple consequences on other elements. The taxonomy allows for a more nuanced discussion of previous findings in the marketplace literature.

The research further advances the literature on business model innovation. First, the cross-case analysis has shown that numerous opportunities for business model innovation exist based on matching previously unconnected markets. However, the research demonstrates that most business models might be novel to their industry, but that all marketplaces essentially build on one of six BM types. In fact, the sample indicates that some of the marketplaces rather imitate existing business models and therefore do not create or expand any market. Research has identified that the novelty and innovativeness of a business model is a key success determinant and drivers of firm performance (Spieth et al., 2016; Spieth et al., 2014; Zott \& Amit, 2007, 2008). However, assessing the degree of business model innovativeness remains a challenge to researchers and analysts. In this regard, the morphological box and the classification system enable a theoretically grounded analysis of their novelty. Besides, the research supports a more nuanced understanding about the relationship between technological innovations and business model innovation. For some of the studied firms, technological innovations were a prerequisite for their business models; but an innovative digital platform does not yet constitute a business model innovation. The morphological box thus supports a systematic analysis at the business model level that can reveal whether a marketplace builds on truly novel choices of elements and element configurations. Hence, the research contributes to a clearer understanding of the differences between innovation at the business model or product level.

The insights advance the understanding of platforms in general. Platform literature has focused on specific strategic, tactical, and operational decisions, including pricing (Hagiu, 2009), openness (Boudreau, 2010; Gawer, 2015; Casadesus-Masanell \& Hałaburda, 2014; Boudreau, 2007), complementor acquisition (Kim et al., 2016; Boudreau \& Jeppesen, 2015), and competitive strategies (Hagiu, 2014; Parker \& van Alstyne, 2015; Zhu \& Iansiti, 2012). The developed framework integrates and expands these multiple dimensions through a business model perspective. Given that platform literature is characterized by a multitude of competing definitions and understandings (Gawer, 2014; McIntyre \& Srinivasan, 2016), the identified BM types and elements provide an 
applicable framework to establish boundaries of the platform concept. Such a BM perspective can provide a holistic understanding about what a platform business model is - and what it is not.

\section{Conclusions and Future Research}

This paper investigates marketplaces, a highly emerging platform type. Most importantly, it provides a novel taxonomy of their business models. The identified taxonomic clusters suggest that there exist six distinguishable types of marketplace business models: (1) 'efficient product transactions', (2) 'digital product community', (3) 'product aficionados', (4) 'on-demand offline services', (5) online services' and (6) 'peer-to-peer offline services'. The taxonomy can serve entrepreneurs and managers in designing, implementing, or evaluating these types of organizations.

The developed taxonomy can provide the basis for several research directions. The findings add to the growing field of enterprise classifications based on the business model as a unit of analysis. While most existing business model-based classifications take place within the boundaries of a specific industry or region (Lambert \& Davidson, 2013), this research is one of the first to empirically classify business models across industry borders. This taxonomy therefore allows for new perspectives on value creation and firm performance of multi-sided business models like marketplaces. Future research can investigate the relationships among the attribute specifications and their causal influence on firm performance.

The taxonomy further allows for a more integrative understanding of novel organizational forms and phenomena that are recently discussed in separated research streams. Integrating knowledge on platforms, platformbased ecosystems, and networks (McIntyre \& Srinivasan, 2016) can contribute to a better understanding of how marketplaces create, deliver, and capture value and compete among each other. While we are not the first to point out the overlapping interest in these fields, our taxonomy can lead to a more nuanced understanding about the distinctive business model types in these organizational forms. As the taxonomy provides first empirically grounded insights about marketplaces discussed in the context of the sharing economy, it can further contribute to a better understanding about what distinguishes sharing-based marketplaces. Thus, we hope to contribute towards more integrative research on these highly relevant phenomena that can transcend the current differences in terminology.

The chosen methodology is not without limitations. First, the empirical findings are derived from entrepreneurial ventures. This decision can limit the reliability of the empirical findings in regards to selected BM elements. For instance, many of the studied BMs only operated in one country. As the ventures grow, it is likely that they will expand their geographic scope. While the findings have provided general insights into the nature of all types of marketplaces and platforms, it would be interesting to replicate the study for established firms. Second, we recognize that the chosen methodology has certain limitations. Objectively evaluating the business models' key activities and resources was rather challenging, as information on where marketplaces invest 
their resources and how they prioritize their activities is scarce. For instance, most marketplaces combine a variety of activities for creating trust among participants, including active community management, curation of listings, a conflict resolution program, or a money-back guarantee. While these mechanisms contribute to a marketplace's value creation, the methodological approach does not allow verifying their relevance to a specific business model. To overcome this limitation, future research could further conduct interviews with decision makers of the complete set of marketplaces. Also, the approach did not allow capturing whether the marketplaces had changed their BM at some point. While BM innovation is outside the scope of this study, future research could take a longitudinal perspective to investigate such BM changes and explore potential change patterns throughout a firm's or market's lifecycle. Third, we observed some linkage between the BM types and the start-ups' geographic locations. For instance, many of the servicecentered marketplaces are based in the San Francisco Bay Area (California). This suggests that certain environmental factors might act as contingencies for the suitability of one BM type or another. Future research could build on the empirical findings to develop hypotheses about the influence of institutional and ecosystem factors on BM decisions and BM performance. A fourth limitation relates to the reliability of the taxonomy's completeness. While we are confident that the taxonomy captures the relevant BM types at present, future technological advances might enable additional types. Finally, we encourage future research to apply our taxonomy to derive insights on differences in the performance outcomes of marketplaces. 


\section{References}

Abdelkafi, N., Makhotin, S., \& Posselt, T. (2013). Business model innovations for electric mobility what can be learned from existing business model patterns? International Journal of Innovation Management, 17, 1-41.

Abdelkafi, N., \& Täuscher, K. (2016). Business Models for Sustainability From a System Dynamics Perspective. Organization \& Environment, 29, 74-96.

Amit, R., \& Zott, C. (2001). Value Creation in e-Business. Strategic Management Journal, 22, 493520.

Baden-Fuller, C., \& Mangematin, V. (2013). Business models: A challenging agenda. Strategic Organization, 11, 418-427.

Bakos, Y. (1998). The emerging role of electronic marketplaces on the internet. Communications of the ACM $, 41,35-42$.

Balocco, R., Perego, A., \& Perotti, S. (2010). B2b eMarketplaces A classification framework to analyse business models and critical success factors. Industrial Management and Data Systems, 110, 11171137.

Boudreau, K. (2010). Open Platform Strategies and Innovation: Granting Access vs. Devolving Control. Management Science, 56, 1849-1872.

Boudreau, K. J. (2007). Does Opening a Platform Stimulate Innovation?: The Effect on Systemic and Modular Innovations. SSRN Electronic Journal.

Boudreau, K. J., \& Jeppesen, L. B. (2015). Unpaid crowd complementors: The platform network effect mirage. Strategic Management Journal, 36, 1761-1777.

Brettel, M., Strese, S., \& Flatten, T. C. (2012). Improving the performance of business models with relationship marketing efforts - An entrepreneurial perspective. European Management Journal, 30, 85-98.

Brunn, P., Jensen, M., \& Skovgaard, J. (2002). e-Marketplaces. European Management Journal, 20 , 286-298.

Casadesus-Masanell, R., \& Hałaburda, H. (2014). When Does a Platform Create Value by Limiting Choice? Journal of Economics \& Management Strategy, 23, 259-293.

CB Insights (2017). The Complete List of Unicorn Companies. https://www.cbinsights.com/researchunicorn-companies. Accessed 05.02.2017.

Choudary, S. P. (2015). Platform scale: How an emerging business model helps startups build large empires with minimum investment. (First edition). S.L.: Platform Thinking Labs Pte. Ltd.

Choudhury, V., Hartzel, K. S., \& Konsynski, B. R. (1998). Uses and consequences of electronic markets: An empirical investigation in the aircraft parts industry. MIS Quarterly: Management Information Systems, 22, 471-503.

Collins, K. M. T., Onwuegbuzie, A. J., \& Sutton, I. L. (2006). A Model Incorporating the Rationale and Purpose for Conducting Mixed-Methods Research in Special Education and beyond. Learning Disabilities: A Contemporary Journal, 4, 67-100.

Cramer, J., \& Krueger, A. B. (2016). Disruptive Change in the Taxi Business: The Case of Uber $\dagger$. American Economic Review, 106, 177-182.

Creswell, J. W. (2014). Research design: Qualitative, quantitative, and mixed methods approaches. (4. ed.). Los Angeles: SAGE Publications.

Creswell, J. W., \& Plano Clark, V. L. (2007). Designing and conducting mixed methods research. Thousand Oaks, Calif.: SAGE Publications.

Dai, Q., \& Kauffman, R. (2001). Business models for internet-based E-procurement systems and B2B electronic markets: An exploratory assessment. Proceedings of the Hawaii International Conference on System Sciences, 158.

Denscombe, M. (2008). Communities of practice: A research paradigm for the mixed methods approach. Journal of Mixed Methods Research, 2, 270-283. 
Engström, A., \& Salehi-Sangari, E. (2007). Assessment of Business-to-Business (B2B): EMarketplaces' performance: Luleå tekniska universitet.

Evans, P. C., \& Gawer, A. (2016). The Rise of the Platform Enterprise: A Global Survey. http://www.thecge.net/wp-content/uploads/2016/01/PDF-WEB-Platform-Survey_01_12.pdf. Accessed 12.09.2016.

Friedman, G. (2014). Workers without employers: Shadow corporations and the rise of the gig economy. Review of Keynesian economics, 2, 171-188.

Gawer, A. (2014). Bridging differing perspectives on technological platforms: Toward an integrative framework. Research Policy, 43, 1239-1249.

Gawer, A. (2015). What Drives Shifts in Platform Boundaries? An Organizational Perspective. Academy of Management Proceedings.

Giaglis, G. M., Klein, S., \& O'Keefe, R. M. (2002). The role of intermediaries in electronic marketplaces: Developing a contingency model. Information Systems Journal, 12, 231-246.

Gurley, B. (2015). How to Miss By a Mile: An Alternative Look at Uber's Potential Market Size. http://abovethecrowd.com/2014/07/11/how-to-miss-by-a-mile-an-alternative-look-at-uberspotential-market-size/. Accessed 28.06.2016.

Hagiu, A. (2009). Two-sided platforms: Product variety and pricing structures. Journal of economics \& management strategy JEMS, 18, 1011-1043.

Hagiu, A. (2014). Strategic decisions for multisided platforms. MIT Sloan Management Review, 55, 7180.

Hagiu, A., \& Wright, J. (2015). Marketplace or Reseller? Management Science, 61, 184-203.

Hamari, J., Sjöklint, M., \& Ukkonen, A. (2016). The sharing economy: Why people participate in collaborative consumption. Journal of the Association for Information Science and Technology, 67, 2047-2059.

Hartmann, P. M., Zaki, M., Feldmann, N., \& Neely, A. (2014). Big Data for Big Business? A Taxonomy of Data-driven Business Models used by Start-up Firms. Working Paper. Cambridge, UK.

Im, K., \& Cho, H. (2013). A Systematic Approach for Developing a New Business Model Using Morphological Analysis and Integrated Fuzzy Approach. Expert Syst. Appl., 40, 4463-4477.

Johnson, M. W. (2010). Seizing the white space: Business model innovation for growth and renewal. Boston, Mass: Harvard Business Press.

Johnson, M. W., Christensen, C. M., \& Kagermann, H. (2008). Reinventing your business model. Harvard Business Review, 86, 50-59.

Kaplan, S., \& Sawhney, M. (1999). B2B E-Commerce Hubs: Towards a Taxonomy of Business Models.

Kenney, M., \& Zysman, J. (2016). The Rise of the Platform Economy. Issues in Science and Technology, 32, 61-69.

Ketchen, D. J., \& Shook, C. L. (1996). The application of cluster analysis in strategic management research: An analysis and critique. Strategic Management Journal, 17, 441-458.

Kim, H. J., Kim, I., \& Lee, H. (2016). Third-party mobile app developers' continued participation in platform-centric ecosystems: An empirical investigation of two different mechanisms. International Journal of Information Management, 36, 44-59.

Kley, F., Lerch, C., \& Dallinger, D. (2011). New business models for electric cars-A holistic approach. Energy Policy, 39, 3392-3403.

Lambert, S., \& Davidson, R. (2013). Applications of the business model in studies of enterprise success, innovation and classification: An analysis of empirical research from 1996 to 2010. European Management Journal, 31, 668-681.

Laudien, S. M., \& Daxböck, B. (2016a). Business model innovation processes of average market players: A qualitative-empirical analysis. $R \& D$ Management, Advance online publication.

Laudien, S. M., \& Daxböck, B. (2016b). Path dependence as a barrier to business model change in manufacturing firms: insights from a multiple-case study. Journal of Business Economics, 86, 611645. 
Lavassani, M. K., Movahedi, B., \& Kumar, V. (2011). E-marketplaces: Taxonomy of the new collaborative information platform. In E-novation for competitive advantage in collaborative globalization technologies for emerging e-business strategies (pp. 16-33). Hershey, Pa.: Business Science Reference.

Leask, G., \& Parker, D. (2007). Strategic groups, competitive groups and performance within the UK pharmaceutical industry: Improving our understanding of the competitive process. Strategic Management Journal, 28, 723-745.

Lee, C., Park, H., \& Park, Y. (2013). Keeping abreast of technology-driven business model evolution: A dynamic patent analysis approach. Technology Analysis \& Strategic Management, 25, 487-505.

Martin, C. J. (2016). The sharing economy: A pathway to sustainability or a nightmarish form of neoliberal capitalism? Ecological Economics, 121, 149-159.

McIntyre, D. P., \& Srinivasan, A. (2016). Networks, Platforms, and Strategies: Emergent Views and Next Steps. Strategic Management Journal.

Milligan, G. W. (1995). Cluster analysis. Working paper series, WPS 95-2. Columbus, Ohio: College of Business, Ohio State University.

Möhlmann, M. (2015). Collaborative consumption: determinants of satisfaction and the likelihood of using a sharing economy option again. Journal of Consumer Behaviour, 14, 193-207.

Ordanini, A., \& Pol, A. (2001). Infomediation and competitive advantage in b2b digital marketplaces. European Management Journal, 19, 276-285.

Osterwalder, A. (2004). The Business Model Ontology - A Proposition in a Design Science Approach. Dissertation. Lausanne, Switzerland.

Parker, G., \& van Alstyne, M. W. (2015). Platform Strategy.

Parker, G. G., van Alstyne, M., \& Choudary, S. P. (2016). Platform revolution: How networked markets are transforming the economy - and how to make them work for you. (First edition).

Pavlou, P. A., \& Dimoka, A. (2006). The nature and role of feedback text comments in online marketplaces: Implications for trust building, price premiums and seller differentiation. Information Systems Research, 17, 392-414.

Peters, C., Blohm, I., \& Leimeister, J. M. (2015). Anatomy of Successful Business Models for Complex Services: Insights from the Telemedicine Field. Journal of Management Information Systems, 32, 75-104.

Pousttchi, K., Schiessler, M., \& Wiedemann, D. G. (2009). Proposing a comprehensive framework for analysis and engineering of mobile payment business models. Information Systems and e-Business Management, 7, 363-393.

Sabatier, V., Mangematin, V., \& Rousselle, T. (2010). From Recipe to Dinner: Business Model Portfolios in the European Biopharmaceutical Industry. Long Range Planning, 43, 431-447.

Saebi, T., \& Foss, N. J. (2015). Business models for open innovation: Matching heterogeneous open innovation strategies with business model dimensions. European Management Journal, 33, 201213.

Schief, M., Pussep, A., \& Buxmann, P. (2013). The Impact of Software Business Model Characteristics on Firm Performance. In G. Herzwurm, \& T. Margaria (Eds.), Software Business. From Physical Products to Software Services and Solutions (pp. 1-12): Springer Berlin Heidelberg.

Schlie, E., Rheinboldt, J., \& Waesche, N. M. (2011). Simply seven: Seven ways to create to sustainable internet business. IE business publishing. Houndmills, Basingstoke: Palgrave Macmillan.

Spieth, P., Schneckenberg, D., \& Matzler, K. (2016). Exploring the linkage between business model (\&) innovation and the strategy of the firm. $R \& D$ Management, 46.

Spieth, P., Schneckenberg, D., \& Ricart, J. E. (2014). Business model innovation - state of the art and future challenges for the field. $R \& D$ Management, 44, 237-247.

Sundararajan, A. (2016). The sharing economy: The end of employment and the rise of crowd-based capitalism. 
Tashakkori, A., \& Teddlie, C. (2003). Handbook of mixed methods in social \& behavioral sciences. Thousand Oaks, Calif.: SAGE Publications.

Täuscher, K. (2016). Leveraging collective intelligence: How to design and manage crowd-based business models. Business Horizons, 60, 237-245.

Täuscher, K., \& Abdelkafi, N. (2017). Visual Tools for Business Model Innovation: Recommendations from a Cognitive Perspective. Creativity and Innovation Management, 26, 1-23.

Täuscher, K., \& Chafac, M. (2016). Supporting business model decisions: a scenario-based simulation approach. Int. J. Markets and Business Systems, 2, 45-67.

Teece, D. J. (2010). Business Models, Business Strategy and Innovation. Long Range Planning, 43, $172-194$.

Vesa, J., \& van Heck, E. (2005). Factors in Adopting Multi-access Technologies in Online Consumer Auction Markets in Finland. European Management Journal, 23, 182-194.

Wang, S., Zheng, S., Xu, L., Li, D., \& Meng, H. (2008). A literature review of electronic marketplace research: Themes, theories and an integrative framework. Information Systems Frontiers, 10, 555571.

Wirtz, B. W. (2015). Business Model Management: Design - Instruments - Success Factors. (2. nd ed. 2015). Wiesbaden: Springer Fachmedien Wiesbaden GmbH.

Zervas, G., Byers, J., \& Proserpio, D. (2013). The Rise of the Sharing Economy: Estimating the Impact of Airbnb on the Hotel Industry. SSRN Electronic Journal.

Zhu, F., \& Iansiti, M. (2012). Entry into platform-based markets. Strategic Management Journal, 33, 88-106.

Zott, C., \& Amit, R. (2007). Business Model Design and the Performance of Entrepreneurial Firms. Organization Science, 18, 181-199.

Zott, C., \& Amit, R. (2008). The fit between product market strategy and business model: implications for firm performance. Strategic Management Journal, 29, 1-26.

Zott, C., Amit, R., \& Massa, L. (2011). The Business Model: Recent Developments and Future Research. Journal of Management, 37, 1019-1042. 